\title{
PENYAKIT DAN KELAPARAN: \\ TELAAH PERKATAAN YESUS DALAM LUKAS 21:11 DAN RELEVANSINYA BAGI GEREJA DI MASA PANDEMI COVID-19
}

\author{
Stephano Ololida Seisala A. \\ STT Bethel Indonesia \\ stephanoambesa@gmail.com
}

\begin{abstract}
This paper is a library research that uses library material as a source of data, to examine Jesus' Words in Luke 21:11 about illness and hunger and find their relevance to the Church in the Pandemic Period. The primary data source in this study is the Gospel of Luke 21:11 which is exposition by the author, supported by secondary data sources namely documents, books and references that are relevant to the problems in this study, and see the current condition of the Covid-19 pandemic. The results of this study suggest how the attitude should be taken by the Church in the midst of the Covid-19 pandemic: First, the church must be happy because it understands why illness and hunger are "permitted" to occur in our country and even the world. Second, the church today is not surprised, frightened and panicked in facing illness and economic crisis that has caused famine. Third, the difficult time is treated as an opportunity to witness. Fourth, the church must strengthen His people that whoever persists in faith in the Messiah in the midst of his suffering, he will have a true and full life, that is, eternal life.
\end{abstract}

Keywords: Disease, Hunger, Jesus' Words, Luke 21:11, Church, Pandemic, Covid-19

\begin{abstract}
Abstrak
Tulisan ini merupakan penelitian kepustakaan (library research) yang menjadikan bahan pustaka sebagai sumber data, untuk menelaah Perkataan Yesus dalam Lukas 21:11 tentang penyakit dan kelaparan dan menemmukan relevansinya bagi Gereja di Masa Pandemi. Sumber data primer dalam penelitian ini adalah Kitab Injil Lukas 21:11 yang dieksposisi oleh penulis, didukung oleh sumber data sekunder yaitu dokumen-dokumen, buku-buku dan referensi yang relevan dengan permasalahan dalam penelitian ini, serta melihat kondisi terkini pandemi Covid-19. Hasil penelitian ini memberikan saran bagaimana sikap yang harus diambil oleh Gereja di tengahtengah pandemi Covid-19: Pertama, gereja harus berbahagia karena memahami mengapa penyakit dan kelaparan "diizinkan" terjadi di negeri kita bahkan dunia. Kedua, gereja pada masa kini tidak menjadi terkejut, takut dan panik mengadapi penyakitan dan krisis ekonomi yang mengakibat kelaparan. Ketiga, masa sulit disikapi sebagai kesempatan untuk bersaksi. Keempat, gereja harus menguatkan umat-Nya bahwa barangsiapa tetap bertahan dalam iman kepada Mesias di tengah-tengah penderitaannya, ia akan memeroleh hidup yang sejati dan penuh, yaitu hidup kekal.
\end{abstract}

Kata Kunci : Penyakit, Kelaparan, Perkataan Yesus, Lukas 21:11, Gereja, Pandemi, Covid-19

\section{PENDAHULUAN}

Injil Lukas adalah satu dari empat

Injil dan merupakan salah satu kitab yang besar di dalam Perjanjian Baru
(Daffinbaugh, 1996:3). Jika digabungkan

dengan Kisah Para Rasul, kedua karya

Lukas ini merupakan kitab yang terpanjang

di dalam Perjanjian baru mencapai $26 \%$ 
(Santosa, 2006:12) dan bahkan mungkin 27,1\% (Bock, 2011:95). Dengan rinci Bock, mengutip Kurt dan Barbara Aland, menampilkan bahwa Lukas dan Kisah Para Rasul memiliki 2.157 ayat dari 7.947 ayat dalam keseluruhan Perjanjian Baru (Allan, 1987:29). Meskipun Paulus menulis kitab terbanyak, yaitu 13 kitab, namun panjangnya hanya 2.032 ayat $(25,6 \%$ dari keseluruha Perjanjian Baru) dan Yohanes yang menulis 4 atau mungkin 5 kitab dengan panjangnya 1.407 ayat, atau sekitar 17,7\% dari keseluruhan Perjanjian Baru (Bock, 2011:95). Bahkan menurut Wilcock (Wilcock, 1979:11) dan pengamatan Daffinbuagh (Daffinbaugh, 1996:3), Injil Lukas sendiri adalah kitab terpanjang dalam Perjanjian Baru.

Dari fakta di atas, Injil Lukas memunyai tempat yang penting bagi gereja pada zaman penulisan Injil dan juga bagi gereja masa kini. Kepentingannya bukan hanya karena Injil ketiga ini adalah kitab terpanjang di dalam Perjanjian Baru, melainkan pertama-tama karena tujuan penulisannya sangat penting. Di mana kita dapat membaca tujuan penulisannya. Lukas menuliskan dalam pendahuluan Injilnya, katanya di dalam Lukas 1:1-4 :

"Teofilus yang mulia, Banyak orang telah berusaha menyusun suatu berita tentang peristiwa-peristiwa yang telah terjadi di antara kita, seperti yang disampaikan kepada kita oleh mereka, yang dari semula adalah saksi mata dan pelayan Firman. Karena itu, setelah aku menyelidiki segala peristiwa itu dengan seksama dari asal mulanya, aku mengambil keputusan untuk membukukannya dengan teratur bagimu, supaya engkau dapat mengetahui, bahwa segala sesuatu yang diajarkan kepadamu sungguh benar."

Dari keempat ayat pertama Injil Lukas ini didapatkan beberapa tujuan penulisnya. Pertama, Lukas adalah orang bukan Yahudi dan menulis Injilnya bagi orang bukan Yahudi pula. Lukas adalah satu-satunya penulis kitab yang berasal dari kalangan orang bukan Yahudi dalam Perjanjian Lama maupun Pejanjian Baru. Ia menulis Injilnya ditujukan kepada Teofilus yang mulia. Kata "yang mulia" (Yun: Kpó $\iota \sigma \tau \varepsilon$, Kratiste) menujukan bahwa ia adalah seorang penjabat pemerintahan Romawi dan tentunya menyiratkan bahwa ia bukan orang Yahudi. (Boland, 1996:10)

Kedua, Lukas tidak puas dengan laporan atau berita tentang Yesus Kristus yang beredar pada saat itu. Banyak berita,

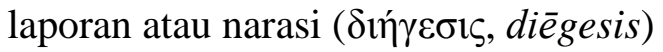
yang ditulis. Ia tidak puas dan mengoreksi hal-hal yang tidak akurat. Ini bukan berarti ia ingin mengoreksi narasi ketiga Injil kanonik lainnya sebagi yang tidak akurat

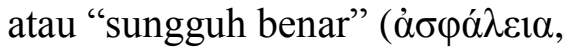
asphaleia), melainkan laporan yang berasal dari tulisan-tulisan "extra-biblical". Memang ada laporan-laporan yang khusus dimiliki Lukas dan tidak ada di dalam Injil lainnya atau sebaliknya, namun bukan 
berarti Lukas lebih akurat dari Injil lainnya atau sebaliknya. Jika kasusnya demikian, kita dapat memandangnya bahwa Lukas melengkapi Injil lainnya atau Injil lainnya melengkapi Lukas. Tetapi berita-berita tentang Yesus di luar Alkitab yang telah membuat Lukas "gerah" atau tidak puas (Barclay, 2017:11), dan berkata: "Karena itu, setelah aku menyelidiki segala peristiwa itu dengan seksama dari asal mulanya, aku mengambil keputusan untuk membukukannya dengan teratur bagimu, supaya engkau dapat mengetahui, bahwa segala sesuatu yang diajarkan kepadamu sungguh benar" (Luk. 1:3-4).

Ketiga, tulisan Lukas berakar dari sejarah. Sebagai ahli sejarah dalam melihat Injil Lukas, Deffinbaugh mengatakan (Daffinbaugh, 1996:4):

\section{"Luke seems intent on presenting a carefully arranged sequence of events, form very beginning, somethings which cannot be claim by other gospel accounts... . Luke, as a historian, delas with the 'root of Jesus' ministry... . The unique contribution of Luke to biblical record of the earliest events in the life and ministry ... of our Lord".}

Memerhatikan dengan seksama bagaimana kontribusi Injil Lukas perihal kepanjangan dan tujuan penulisannya, sangat penting bagi gereja segala zaman mempelajari Injil ini dengan seksama pula. Laporan Lukas bukan hanya mengoreksi apa yang didengar oleh Teofilus dan gereja pada zaman dulu, tetapi juga mengoreksi berita yang didengar gereja sekarang tentang Yesus, Tuhan kita. Mari kita pelajari Injil Lukas dengan tekun!

\section{METODE PENELITIAN}

Tulisan ini merupakan penelitian kepustakaan (library research) yang menjadikan bahan pustaka sebagai sumber data, untuk menelaah Perkataan Yesus dalam Lukas 21:11 tentang penyakit dan kelaparan dan menemmukan relevansinya bagi Gereja di Masa Pandemi. Sumber data primer dalam penelitian ini adalah Kitab Injil Lukas 21:11 yang dieksposisi oleh penulis, didukung oleh sumber data sekunder yaitu dokumen-dokumen, bukubuku dan referensi yang relevan dengan permasalahan dalam penelitian ini, serta melihat kondisi terkini pandemi Covid-19. Hasil penelitian ini memberikan saran bagaimana sikap yang harus diambil oleh Gereja di tengah-tengah pandemi Covid-19.

\section{HASIL DAN PEMBAHASAN}

\section{Genre Lukas 21:7-19}

Injil Lukas secara umum seringkali disebut ber-genre injil, sejarah dan narasi. Pertanyan yang mendasar dan masih menjadi perdebatan adalah apa itu Injil. Perdebatan dan diskusinya dipaparkan dengan baik oleh Joel B. Green dalam bukunya "Memahami Injil-Injil dan Kisah Para Rasul” (Green, 2005:61). Secara sederhana Injil adalah kabar baik yang meliputi tiga perkara, yaitu pertama, sebagai pemberitaan firman. Sebab itu tulisan di dalam injil memberitakan yang 
menyaksikan karya penebusan Allah di dalam kehidupan Yesus dari Nazaret yang berorotitas dan tidak terkait konteks waktu (Green, 2005:64). Kedua, dengan menyebut Injil sebagai “pemberitaan firman" kita mengerti bahwa Allah berbicara melalui Injil. Melalui kata-kata dan tindakan-tindakan Yesus yang terekam dalam Injil, Sang Tuhan yang telah bangkit dari dari antara orang mati, kembali hidup dan kehidupan-Nya ini memiliki otoritas untuk berbicara kepada suatu generasi baru sebagai usaha penulis injil untuk pekabaran Injil (Green, 2005:64-65). Ketiga, sebagai "pemberitaan firman", Injil merupakan kombinasi sejarah dan dan teologi. Kisah Yesus yang historis diinterpretasikan sedemikan rupa sebagai ajaran teologis (Green, 2005:65). Sebagai berita yang historis dan teologi, I. Howard Mashall membahas Injil Lukas dan Kisah Para Rasul sebagai history dan teologi dalam bukunya, "Luke: Historian and Theologian". (Mashal, 1971)

Telah disinggung di atas, Injil juga ber-genre sejarah. Jika Injil adalah pemberitaan firman, maka penulis Injil memberitakan Injil melalui sejarah. Kesejarahan Injil memang dengan sengit diperbedatkan, tetapi tidak terbantahkan dalam fakta-kata historis di dalam Injil itu sendiri (Green, 2005:83). Fakta-fakta historis dikumpulkan penginjil bukan dengan sejarah semata, tetapi fakta historis demi mengajarkan komunitasnya untuk sebuah pesan teologis. Santoso mengutip pendapat Stephen Wilson dalam bukunya "The Gentiles and the Gentile Mission in Luke-Acts", R. P. Martin dan bukunya "New Testament Foundation Vol. 1" untuk mendukung pendapatnya bahwa Injil Lukas mengumpulkan fakta-fakta historis tentang Yesus untuk membangun pesan teologis bagi komunitasnya (Santosa, 2006:21), dan tentunya juga Injil-Injil lain. (Green, 2005:83)

Tentunya, sebagai pemberitaan firman, Injil merupakan teologi seperti dinyatakan di atas bahwa para penginjil mengumpulkan fakta-fakta historis Yesus bukan demi sejarah semata, tetapi demi juga membangun ajaran teologis. Dan sangat menarik pemberitaan ajaran teologis para penginjil disampaikan dalam sebuah narasi.

Setelah menguraikan tentang genre Injil Lukas, kita dapat menyimpulkan bahwa sesungguhnya, seperti Injil-Injil kanonik lain, Injil Lukas ber-genre Injil, sejarah dan dan teologi. Namun yang menarik para penginjil menyampaikan pemberitaan firman yang merupakan kabar baik yang berdasarkan fakta-fakta historis karya keselamatan Allah di dalam Yesus Kristus sebagai ajaran teologis dalam bentuk naratif. Jadi, Injil Lukas adalah sebuah narasi teologis (Stonstad, 1994:5). O. C. Oswald menulis buku yang baik dengan menampilkan "Injil Lukas Sebagai Cerita". 
Sekarang kita memasuki

pembahasan inti tentang perikop Lukas

21:7-19 yang merupakan pemberitaan

Yesus tentang penderitan para murid-Nya.

Secara umum, tentunya perikop ini pun

merupakan kabar baik yang berdasarkan

fakta sejarah yang adalah ajaran teologis

Yesus yang dinarasikan oleh Lukas.

Namun setelah mempelajari perikop

tersebut dari beberapa sumber, perikop

Lukas 21:7-19 bersifat apokaliptis.

Nah, untuk bisa melakukan

penalaahan terhadap perikop ini dengan

baik, kita harus mengenali karakteristik

sastra apokaliptis. Boland memulai

penelaahan perikop Lukas 21:5-38 dengan

kalimat pembuka: "dengan kata Yunani isi

bagian ini disebutkan apokalipsis. ...

Apokalipsis karangan yang mau

menyingkapkan masa depan yang masih

tersembunyi” (Boland, 1996:501). Dengan

mengikuti pola pikir Boland, kita

menemukan empat unsur tulisan yang ber-

genre apokaliptis. Pertama, apokaliptis

selalu menyuarakan "Hari TUHAN". Pada

hari itu akan terjadi peralihan dari "dunia

masa kini" (olam hazzeh, tatanan masa

kini) yang jahat ke "dunia zaman masa

akan datang" (olam haba', tatanan masa

akan datang) yang baik (bnd. Amos 5:18-

20). Waktu melukiskan akan datangnya

hari TUHAN itu biasanya digunakan

gambaran-gambaran "akan terjadi gempa

bumi yang dahsyat dan di berbagai tempat

akan ada penyakit sampar dan kelaparan, dan akan terjadi juga hal-hal yang

mengejutkan dan tanda-tanda yang dahsyat dari langit" dan perikop Injil Lukas ini memenuhi kreteria ini (lihat Lukas 21:11). Kedua, pemberitaan tentang pengrusakan Yerusalem dan Bait Suci seperti yang dikumandangkan nabi Yeremia dalam kitab Yeremia pasal 7. Pengrusakan Yerusalem dan Bait Suci ini karena dosa bangsa Israel. Yesus pun mengumandangkan hal yang sama seperti nabi Yerenia, katanya: “Apa yang kamu lihat di situ - akan datang harinya di mana tidak ada satu batupun akan dibiarkan terletak di atas batu yang lain; semuanya akan diruntuhkan" (Luk 21:6). Ketiga, sastra apokaliptis menceritakan bahwa pada hari TUHAN itu akan terjadi penghakiman dengan datangnya Anak Manusia dalam kemuliaaan dengan kuasa penghakiman yang telah diserahkan Allah kepada-Nya (bnd. Daniel 7:13-14).

Kedatangan Anak Manusia dalam kemuliaan-Nya juga diberitakan Yesus, yang diistilahkan dengan kata "parousia", pada hari itu. Pengrusakan Yerusalem dan Bait Suci yang terjadi pada tahun 70 bukan penhakiman ilahi pada hari TUHAN. Leon Morris mengomentari Perikop Lukas 21 dengan mengatakan: "Dalam keseluruhan percakapan itu Lukas, secara lebih jelas daripada penulis lain, menjelaskan bahwa penghancuran Yerusalem berbeda sekali dengan parousia, ...” (Morris, 1996:305). jadi, sastra apokaliptis memuatkan 
parousia. Keempat, menjelang akhir zaman, apokaliptis Perjanjina Lama dan Perjanjian Baru menceritakan terjadi penindasan dan penganiayaan terhadap orang saleh. Daniel 12:1 mencatat: "Pada waktu itu juga akan muncul Mikhael, pemimpin besar itu, yang akan mendampingi anak-anak bangsamu; dan akan ada suatu waktu kesesakan yang besar, seperti yang belum pernah terjadi sejak ada bangsa-bangsa sampai pada waktu itu ...". Yesus pun memberitakan hal yang sama (Boland, 501-502), katanya:

“Tetapi sebelum semuanya itu kamu akan ditangkap dan dianiaya; kamu akan diserahkan ke rumah-rumah ibadat dan penjara-penjara, dan kamu akan dihadapkan kepada raja-raja dan penguasapenguasa oleh karena nama-Ku. Hal itu akan menjadi kesempatan bagimu untuk bersaksi” (Luk. 21:12-13).

Nah, sekarang kita dapat menyimpulkan bahwa keseluruhan Lukas 21 yang dimulai ayat 5 sampai 28 memiliki genre apokaliptis. Jadi, perikop Lukas 21:7-19 juga apokaliptis. Jika kita akan menelaah tentang kelaparan dan penyakit yang terdapat di dalam Lukas 21:11, kita tidak boleh melupakan bahwa ajaran teologis Yesus ini bersifat apokaliptis.

\section{Penelaah Terhadap Perkataan Yesus} tentang Penyakit dan Kelaparan di dalam Lukas 21:11
Konteks ayat 11 ini adalah Lukas 21:5-19 tentang pemberitaan Yesus akan penderitaan para murid-Nya. Sebelum menelaah Lukas 21:11, dengan memperhatikan konteks Lukas 21:5-19, bahkan ayat-ayat berikutnya, kita harus menanamkan dalam pikiran dan hati kita bahwa genre Lukas 21:5 dan seterusnya adalah apokaliptis. Memang ketika membaca dengan serius, kisahnya sangat menakutkan dan banyak orang percaya takut dibuatnya. Ketika kita merasa takut membaca tulisan yang ber-genre apokaliptis, seperti kebanyakan orang, maka kita mempunyai kesalahan perspektif terhadap tulisan apokaliptis. Contohnya, banyak orang percaya ketakutan ketika membaca kitab Wahyu. Jelas, orang percaya yang takut mempunyai perspekstif yang salah terhadap kitab Apokaliptis Wahyu. Penulis kitab Apokaliptis Wahyu mengatakan dan pembaca harus mendengar dengan seksama yang dikatakan supaya tidak salah perspektif:

"Yohanes telah bersaksi tentang firman
Allah dan tentang kesaksian yang
diberikan oleh Yesus Kristus, yaitu
segala sesuatu yang telah
dilihatnya. Berbahagialah ia yang
membacakan dan mereka yang
mendengarkan kata-kata nubuat ini,
dan yang menuruti apa yang ada
tertulis di dalamnya, sebab waktunya
sudah dekat". (Wahyu 1:2-3)

Jadi, dalam membaca tulisan apokaliptis, kita harus berbahagia, apalagi memahaminya. Meski Yesus 
memberitakan tentang penghancuran

Yerusalem dan Bait Suci serta penderitaan yang akan dialami para murid, kita harus berbahagia. Sebagai pembaca kita berbahagia bukan karena penghancuran Yerusalem dan Bait Suci, apalagi penderitaan yang akan dialami para murid. Kita berbahagia karena memahami maksud dan makna nubuatan Yesus tersebut.

Menurut nubuatan Yesus, Yerusalem dan Bait Suci akan dirusak. Dan peristiwa pengrusakan Yerusalem dan Bait Suci benar-benar terjadi dalam sejarah Israel pada tahun 70 Masehi yang dilakukna parajurit Romawi yang dipimpin jendral Titus. Yesus berkata: “Apa yang kamu lihat di situ - akan datang harinya di mana tidak ada satu batupun akan dibiarkan terletak di atas batu yang lain; semuanya akan diruntuhkan" (Luk 21:6). Keruntuhan yang dimasuk adalah keruntuhan Bait Suci (lihat konteks Luk 21:5). Penghancuran Bait Suci merupakan pertanda kedatangan Mesias, sebagai Raja diraja, sehingga akan ada orang yang mengaku bahwa ia adalah Sang Mesias (Geldenhuys, 2002:525). Untuk hal itu Yesus mengingatkan dan berkata:

"Waspadalah, supaya kamu jangan disesatkan. Sebab banyak orang akan datang dengan memakai nama-Ku dan berkata: Akulah Dia, dan: Saatnya sudah dekat. Janganlah kamu mengikuti mereka" (Luk 21:8). Jadi, ketika para murid-Nya bertanya: "Guru, bilamanakah itu akan terjadi? Dan apakah tandanya, kalau itu akan terjadi?" (Luk 21:7), mereka bertanya bukan sekedar kapan terjadinya penghancuran Bait Suci dan tentunya juga kota Yerusalem, melainkan bertanya kapan Mesias sebagai Raja diraja datang. Jelas, pertanyaan ini tidak menyiratkan kegelisahan akan terjadinya perintiwa yang mengerikan dan menakutkan, melainkan pengharapan yang penuh kebahagiaan para murid. Karena penuh kebahagiaan, mereka meminta tanda kedatangan Sang Mesias. Apakah ada tanda-tanda yang mendahului kedatanag Mesias, selain penghancuran Bait Suci? Jika ada, apa saja? Yesus menjawab:

"...apabila kamu mendengar tentang
peperangan dan pemberontakan,
janganlah kamu terkejut. Sebab
semuanya itu harus terjadi dahulu ...
Bangsa akan bangkit melawan bangsa
dan kerajaan melawan kerajaan,
11 dan akan terjadi gempa bumi yang
dahsyat dan di berbagai tempat akan
ada penyakit sampar dan kelaparan,
dan akan terjadi juga hal-hal yang
mengejutkan dan tanda-tanda yang
dahsyat dari langit" (Luk 21:9-11).

Namun, sebelum nubutan Yesus di dalam ayat 9-11 itu terjadi, perhatikan, ada peristiwa yang mendahuluinya. Apa itu? Simak baik-baik ynag Yesus katakan: “Tetapi sebelum semuanya itu kamu akan ditangkap dan dianiaya; kamu akan diserahkan ke rumah-rumah ibadat dan penjara-penjara, dan kamu akan dihadapkan kepada raja-raja dan penguasapenguasa oleh karena nama-Ku” (Luk 
21:12). Apakah itu malapetaka bagi para murid? Tentunya, penderitaan itu menyakitkan. Banyak orang menyebutnya sebagai musibah dan bencana yang akan dilalui. Tetapi Yesus tidak menjanjikan bahwa sebagai orang percaya, mereka lepas dari penganiayaan yang mendatangkan penderitaan, malahan mereka harus mengalaminya bukan sebagai bencana, tetapi Yesus berkata:

“...akan menjadi kesempatan bagimu untuk bersaksi. 14 Sebab itu tetapkanlah di dalam hatimu, supaya kamu jangan memikirkan lebih dahulu pembelaanmu. Sebab Aku sendiri akan memberikan kepadamu kata-kata hikmat, sehingga kamu tidak dapat ditentang atau dibantah lawanlawanmu" (Luk 21:14-15).

Penderitaan para murid semakin sempurna, karena “... kamu akan diserahkan juga oleh orang tuamu, saudarasaudaramu, kaum keluargamu dan sahabatsahabatmu dan beberapa orang di antara kamu akan dibunuh dan kamu akan dibenci semua orang oleh karena nama-Ku" (Luk 21:16-17). Apakah Tuhan tidak peduli dan perhatikan orang percaya yang mengalami penderitan yang sempurna ini? Yesus berfirman: "Tetapi tidak sehelaipun dari rambut kepalamu akan hilang. Kalau kamu tetap bertahan, kamu akan memperoleh hidupmu” (Luk 21:18-19). Untuk kedua ayat terakhir ini, Warren W. Wiersbe berkomentar (Wiersbe, 2012:123), katanya:

"Namun, mereka tidak boleh berputus asa karena Allah tetap memegang kendali. Tidak sehelai pun rambut di kepala mereka akan hilang di luar kehendak-Nya yang berkuasa (Mat. 10:28-31). Dengan menyadari hal itu, mereka akan memiliki ketekuan dan kemampuan untuk menghadapi tantang dengan iman dan keteguhan.”

Sedangkan Geldenhuys mengomentar ayat 19 (Geldenhuys, 2002:527), katanya:

"The great essensial, however is that thert faithful must presevere and not lose heart, even thogh they have to go through nomerous periods of disstress and persecutions. Through perseverence they must achieve true and full life, and be spitirually strong and triumphant in all circimtences".

Kehidupan yang sejati dan penuh itu diperoleh oleh mereka yang tekun dan tetap bertahan dalam iman, khusunya bertahan dalam iman kepada penderitaan Yesus yang puncaknya sampai terpaku di kayu salib (Boland, 524-526). Jadi, kehidupan yang sejati dan penuh itu adalah kehidupan kekal.

Nah, dengan memahami pengertian Lukas 21:5-19, kita bisa memahami penyakit sampar dan kelaparan yang terjadi sebelum penghancuran Bait Suci di Yerusalem. Kata "penyakit sampar” ini adalah terjemahan dari kata Yunani

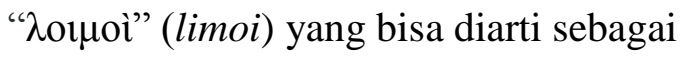
penyakit sampar sebagi tulah atau hukum atas keberdosaan manusia. Meskipun

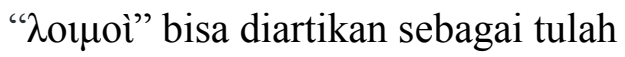
karena dosa, tetapi di dalam konteks Lukas 21 ini tidak jelas apakah penyakit sampar ini sebagi kutukan atas keberdosaan manusia. Lepas dari kutukan atau bukan, penyakit ada setelah keberdosaan Adam, 
ada kalanya Allah mengizinkan sakit penyakit ini menimpa manusia, tidak terkecuali bagi orang percaya. Namun di Lukas 21 ini sebagai tanda yang mendahuli penghancuran Bait Suci.

Tanda lain untuk menjadi fokus diskusi kita adalah kelaparan, yang ditulis dalam teks berbahasa Yunani dengan kata " $\lambda \iota \mu$ oi” (limoi). Kelaparan ini jelas karena keberdosaan manusia, tetapi di sini juga jelas apakah sebagai kutukan Allah. Fungsi kelaparan ini juga sebagai tanda yang mendahului kehancuran dan pengrusakan Bait Suci.

\section{Perlu diperhatikan komentar} Wiersbe terhadap penyakit sampar dan kelaparan yang dinubuatkan Yesus. Ia berkomentar, katanya: “... wabah sakit penyakit, serta bencana kelaparan itu sendiri bukanlah tanda kedatangan-Nya sudah dekat. Peristiwa-peristiwa itu selalu terjadi sepanjang sejarah dunia" (Wiersbe, 2012:121). Yesus pun memeringatkan para murid, katanya: “... Sebab semuanya itu harus terjadi dahulu, tetapi itu tidak berarti kesudahannya akan datang segera" (Luk 21:9). Fakta sejarah membuktikan bahwa penyakit sampai dan kelaparan benar-benar terjadi sebelum penghancuran Bait Suci (Wiersbe, 2012:121). Nubuat Yesus ini tentang sakit penyakit dan kelaparan akan terus terjadi sepanjang sejarah dunia sebelum dunia sekarang ini (olam hazzeh) berakhri pada saat dunia yang akan datang (olam habba) mengantikannya pada waktu hari TUHAN, saat kedatangan Yesus Sang Mesias sebagai Raja diraja. Jadi jika sakit penyakit dan kelalaparan terjadi, ingat peringatan Yesus: “... janganlah kamu terkejut ...: (Luk 21:9). Kata "terkejut" ( $\pi \tau \circ \eta \theta \tilde{\eta} \tau \varepsilon$, ptoethete) berarti takut dalam kepanikan.

Setelah memelajari Lukas 21:11 dalam terang konteksnya, kita dapat menyimpulkan bahwa penyakit dan kelaparan hanyalah tanda sebelum kesudahan, yaitu hari TUHAN di mana Sang Mesias akan datang dalam kemuliaanNya sebagai Raja diraja. Penyakit dan kelaparan terjadi sepanjang sejarah kehidupan manusia di dunia sekarang ini, dan bisa menimpakan semua orang, termasuk orang percaya. Penyakit dan kelaparan terjadi karena dosa manusia, tetapi orang yang tertindak penyakit dan kelaparan bukan semata-mata karena dikutuk Tuhan sebab dosanya. Jika orang percaya harus mengalami sakit penyakit dan kelaparan bukan berarti Allah tidak peduli mereka. Allah tetap mengendalikan jalannya dunia ini. Demikian ciri atau karakteristk sastra apokaliptis. Allah tetap memelihara umat-Nya di tengah-tengah bencana sakit penyakit dan kelaparan. Dan siapa saja yang bertahan di dalam iman kepada Sang Mesias meski mengalami sakit penyakit dan kelaparan, ia akan memperoleh kehidupan yang sejati dan 
penuh, yaitu kehidupan kekal.

\section{SIMPULAN DAN REKOMENDASI}

Apakah yang dapat disimpulkan

dari pemaparan di atas? Bagaimana

relevansi Perkataan Yesus tentang Penyakit dan Kelaparan menurut Lukas 21:11 bagi

Gereja Pada Masa Pandemi Covid-19?

Pada waktu penulis menulis makalah ini, dunia zaman sekarang sedang dilanda sakit penyakit yang mengertikan, yaitu Covid-19 yang disebabkan oleh virus Corona. Mengapa mengerikan? Meski dapat sembuh, namun belum ada obat yang dapat menyembuhkan dan tidak sedikit orang yang terjangkit serta meninggal dunia karenanya. Penularan sakit penyakit ini sangat mudah, sehingga sebagian pemerintah melakukan kebijakan untuk me-“lock-down" negara, bahkan "lockdown" antar kota, kebupaten dan wilayah yang lebih kecil. Pemerintah Indonesia, di mana kita sebagai umat Tuhan tinggal, meski tidak mengambil kebijakan untuk "lockdown", tetapi "Pembatasan Skala Berskala Besar" (PSBB) yang harus dijalankan oleh gubernur, walikota atau bupati tiap daerah. Akibat kebijakan ini, ekonomi Indonesia tergangu. Terjadi pemutusan hubungan kerja (PHK), penghasilan rakyat menurun, terjadi pengangguran dan lain sebaginya. Menyikapi fenomena seperti ini apa yang harus gereja lakukan?

Ada berapa sikap yang harus diambil oleh Gereja di tengah-tengah pandemi Covid-19 ini melanda dunia di sekitar kita. Pertama, gereja harus berbahagia. Gereja bukan berbahagia karena sakit penyakit dan kelaparan yang menimpa negeri kita Indonesia yang tercinta, tetapi berbahagia karena memahami mengapa penyakit dan kelaparan “diizinkan” terjadi di negeri kita bahkan dunia. Ditengah-tengah pandemi yang berlangsung, tangan Allah tidak melepasakn kita sebagi umat-Nya. Yesus berkata: "Tetapi tidak sehelaipun dari rambut kepalamu akan hilang" (Luk 21:18). Berbahagia di sini adalah

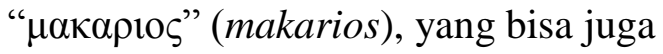
diartikan "blessed" (terberkati). Di tengahtengah pandemi Covid-19, Allah mengizinkan umat-Nya sakit dan kelaparan, tetapi Ia tidak lepas tangan, Itulah bahagia dan berkat umat Tuhan.

Kedua, gereja pada masa kini tidak menjadi terkejut $(\pi \circ \rho \varepsilon v \theta \eta \tau \varepsilon)$, takut dan panik mengadapi penyakitan dan krisis ekonomi yang mengakibat kelaparan. Dengar apa yang Yesus katakan: : “janganlah kamu terkejut”. Penyakit dan kelaparan itu terjadi bukan hanya pada masa kita sekarang, tetapi dari dulu dan generasi gereja mendatang. Gereja sekarang jangan merasa paling menderita sehingga menjadi takut dan panik.

Ketiga, masa sulit bukan hanya tidak boleh disikapi dengan takut dan 
panik, melainkan sebagai kesempatan untuk bersaksi. Yesus berkata: "Hal itu akan menjadi kesempatan bagimu untuk bersaksi” (Luk 21: 13). Ceritakan bahwa sakit penyakit itu adalah tanda yang mendahului kedatangan Sang Mesias. Siapa Mesias itu? Ia adalah Raja diraja yang mengendalikan jalannya dunia. Dia adalah Yesus. Ia akan datang dalam kemuliaan-Nya dan menghakimi dunia.

Keempat, bisa jadi sakit penyakit dan kelaparan yang menimpa kita menyebabkan kita meninggal. Banyak berita yang beredar, para pendeta dan orang Kristen, meninggal dunia karean diserang virus Corona, tetapi jangan membuat kita takut. Gereja harus menguatkan umat-Nya bahwa barangsiapa tetap bertahan dalam iman kepada Mesias di tengah-tengah penderitaannya, ia akan memeroleh hidup yang sejati dan penuh, yaitu hidup kekal. Bagaimana gereja bisa yakin akan memeroleh hidup yang kekal? Yesus berkata: "Kalau kamu tetap bertahan, kamu akan memperoleh hidupmu" ( Luk 21:19).

\section{DAFTAR PUSTAKA}

Aland, Kurt dan Barbara. The Text of the New Testament. Grand rapids, MI: Eerdmans, 1987.

Barclay,William. Pemahaman Alkitab Setiap hari: Injil Lukas . Jakarta: BPK Gunung Mulia, 2017.
Bock, Darrel L. A Biblical Theology of the New Testament. Malang: Peberbit Gandum Mas, 2011.

Boland, B. J. Tafsiran Alkitab: Kitab Injil Lukas . Jakarta: BPK Gunung Mulia, 1996.

Daffinbaugh, Robert. Luke: the Gospel of the Gentiles. Dallas, TX: Biblical Study Press, 1996.

Geldenhuys, Norval. Commentary on the Gospel of Luke. Grand Rapids, MI: Eerdmans, 2002.

Green, Joel B. Memahami Injil-Injil dan Kisah Para Rasul. Jakarta: Pesekutuan Pembaca Alkitab, 2005).

Mashal, I. Howard. Luke: Historoian and Theologian. Grand Rapids, MI: Eerdmans, 1971.

Morris, Leon. Teologi Perjanjian Baru. Malang: Penerbit Gandum Mas, 1996.

Santoso, David Iman. Theologi Lukas: Intisari dan Aplikasinya. Malang: Literatur SAAt, 2006.

Stonstad, Roger. The Charismatic Theology of St. Luke. Peabody, MA: Hendrickson Publishers, 1994.

Wiersbe,Warren W. Seri Tafsiran Lukas 14-24: Teguh di dalam Kristus. Bandung: Yayasan Kalam Hidup, 2012.

Wilcock, Michael. The Massage of Luke: The Bible Speaks Today Series. Downwers Grove: Inter-Versity Press, 1979. 